\title{
PERISTIWA MALAPETAKA LIMA BELAS JANUARI (MALARI) TAHUN 1974 SEBAGAI PEMBELAJARAN SEJARAN KELAS XII SEKOLAH MENENGAH ATAS SRIGUNA PALEMBANG
}

\author{
Oleh: Agi Distrianto*, Sukardi** \\ ${ }^{*}$ Guru sejarah SMA Negeri 1 Jebus \\ *Dosen Program Studi Pendidikan Sejarah FKIP Universitas PGRI Palembang
}

\begin{abstract}
ABSTRAK
Malapetaka lima belas Januari atau yang dikenal masyarakat sebagai peristiwa malari tidak bisa dilihat dari satu sudut pandang. Sebagai sebuah peristiwa politik yang mengkonfrontasikan negara antara Orde Baru dengan masyarakat, malari tentu saja tidak dapat berdiri sendiri. Masalah dalam penelitian ini yaitu bagaimanakah latar belakang, jalannya dan dampaknya peristiwa malari tahun1974 yang dapat dijadikan sebagai sumber pembelajaran sejarah kelas XII Sekolah Menengah Atas Sriguna Palembang. Tujuan penelitian ini untuk mengetahui latar belakang peristiwa malari, untuk mengungkapkan jalannya peristiwa malari, untuk mendeskripsikan dampak adanya malari, dan untuk meneruskan peristiwa malari sebagai sumber pembelajaran sejarah kelas XII Sekolah Menengah Atas Sriguna Palembang. Metode yang digunakan adalah deskriptif kualitatif. Teknik analisis datanya dengan menggunakan data di lapangan. Sumber data studi pustaka, wawancara dan observasi. Hasil penelitian membahas tentang gambaran umum tempat penelitian dan kronologi dan dampak yang ditimbulkan malari.
\end{abstract}

Kata Kunci: Peristiwa, Malari, Sumber Pembelajaran

\section{A. PENDAHULUAN}

Pendidikan sangat penting bagi manusia dalam menyokong tingkat kesejahteraan kehidupan manusia. Pendidikan dapat diartikan sebagai pewarisan budaya serta ilmu pengetahuan dari satu generasi ke-generasi yang lain. Selain sebagai pewarisan budaya pendidikan juga diartikan sebagai suatu kegiatan yang sistematis dan sistemik terarah kepada terbentuknya kepribadian manusia atau peserta didik (Tirtarahardja, 2005:34). Di dalam memperoleh pendidikan dapat diperoleh dari lembaga sekolah yang mempelajari berbagai ilmu pengetahuan salah satunya adalah mata pelajaran sejarah.

Selama rentang merdeka sampai pada masa sekarang Indonesia sudah mengalami masa pergantian sebanyak tujuh kali. Salah satu presiden yang memegang kekuasaan terlama adalah Soeharto yaitu selama hampir 32 tahun. la berhasil berkuasa dengan diterbitkannya "surat perintah sebelas maret" (Supersemar) kepada panglima angkatan darat pada saat itu yaitu Letjen Soeharto. Surat perintah itu memberi wewenang untuk mengambil tindakan yang dianggap perlu untuk memulihkan ketertiban dan keamanan negara (Pambudi, 2009:7).

Dampak dari adanya Supersemar itu langsung terasa yaitu menangkap 15 menteri pendukung Soekarno, memulangkan atau membubarkan Tjakrabirawa (yang terdiri dari 4000 pasukan yang loyal terhadap presiden) serta mengontrol media massa di bawah pusat penerangan angkatan darat (Puspen AD). Tindakan itu untuk mengakhiri kekuasaan Soekarno dan juga memberhentikan dualisme kekuasaan pasca-Gerakan 30 September 1965. Soeharto juga mengubah arah kebijakan yang dibuat Soekarno yaitu tentang penentangan nasionalisme Caltex (Adam, 2010:121).

Dari segi kebijakan ekonomi, banyak yang dibuat oleh para tekhnokrat lulusan barat dari universitas Barkeley sehingga disebut mafia Barkeley yang 
menguntungkan Soeharto dan golongannya. Bahkan Soeharto membuka investasi asing seluas-luasnya terutama negara Jepang yang mempunyai aset penting di Indonesia. Hal ini diperparah dengan rencana kedatangan Perdana Menteri Jepang yang ingin melihat hasil investasinya di Indonesia. Keadaan ini membuat para mahasiswa mulai melakukan aksi demonstrasi pada tahun 1974 yang dikenal dengan peristiwa malapetaka lima belas januari (malari) (Hidayat, 2006:372).

Peristiwa ini pada awalnya merupakan sebuah tindakan yang dilakukan untuk mengkritisi pemerintah orde baru. Mereka menentang penanaman modal asing (PMA) di Indonesia. Sasaran beralih dari para tekhnokrat ke-para investor. Demonstrasi ini terus berlanjut selama kunjungan dua hari ke-Jakarta antara 15-16 Januari 1974. Hal itu diperparahdengan pertentangan antara asisten pribadi presiden yaitu Ali Moertopo dan panglima komkaptip yaitu jendral Soemitro (Caldwell, 2011:317).

Demonstrasi ini berubah dari aksi damai menjadi kerusuhan selama kunjungan Tanaka ke-Indonesia. Meskipun ada peringatan dari komandan militer untuk membubarkan diri dan tindakan itu merupakan tindakan pengkhianatan serta mahasiswa yang merusak barang orang Jepang akan ditembak di tempat. Setelah kepergian Tanaka tentara mulai mengumpulkan aktor intelektual sebagai bagian dari penyelidikan. Pada tanggal 1 Agustus 1974 Hariman Siregar dituntut di pengadilan atas kerusuhan tersebut (Caldwell, 2011:321).

Itulah kenapa reaksi Soeharto sangat keras terhadap peristiwa Malari. Pada 1974 stabilitas dan pemerintah orde baru terbukti rapuh dan mudah goyah. Hal ini membuktikan bahwa banyak kalangan masyarakat yang tidak puas dengan pemerintahan Soeharto. Serta banyak kalangan yang ditangkap dan membredel media massa serta masyarakat dikontrol (Didi, 2008:36).

Karena peristiwa malari tidak tercantum dalam silabus pembelajaran pada kompetensi dasar merekontruksikan perkembangan politik, ekonomi sosial budaya dan pendidikan pada masa Orde Baru tidak dijelaskan secara jelas serta kurang tersedianya sumber pembelajaran sejarah kontroversi sehingga perlu ditambah untuk memberikan pengetahuan yang lebih jelas kepada siswa kelas XII tentang materi malapetaka lima belas Januari (malari) tahun 1974. Sehingga membuat peneliti tertarik untuk meneliti peristiwa malari. Adapun rumusan masalah dalam penelitian ini adalah bagaimanakah latar belakang, jalannya dan dampak peristiwa malapetaka lima belas Januari (malari) tahun 1974 yang dapat dijadikan sebagai sumber pembelajaran sejarah kelas XII Sekolah Menengah Atas Sriguna Palembang?

\section{B. METODE PENELITIAN}

Berdasarkan rumusan masalah, penelitian ini mendeskripsikan secara rinci tentang latar belakang, jalannya dan dampak peristiwa malapetaka lima belas Januari (malari) tahun 1974 sebagai sumber pembelajaran sejarah. Untuk memahami hal tersebut, dilakukan penelitian secara mendalam dengan menggunakan pendekatan deskriptif kualitatif. Sumber Data. Sumber data dalam penelitian ini adalah: Informan, Dokumen. Tempat penelitian di SMA Sriguna Palembang. Teknik Pengumpulan Data: Wawancara Mendalam, Kajian Dokumen, Observasi Langsung. Teknik Cuplikan. Peneliti dalam melakukan kegiatan penelitian ini menggunakan teknik cuplikan purposive sampling. Validitas Data. Validitas data sangat penting dalam proses pemaparan hasil penelitian, pembahasan dan penarikan simpulan. Dengan adanya validitas data triangulasi yang digunakan: triangulasi data, triangulasi metode. 
C. HASIL DAN PEMBAHASAN Hasil Penelitian

1. Latar Belakang Malapetaka Lima Belas Januari (Malari)

Malapetaka lima belas Januari atau yang dikenal masyarakat sebagai peristiwa malari tidak bisa dilihat dari satu sudut pandang. Sebagai sebuah peristiwa politik yang mengkonfrontasikan negara antara Orde Baru dengan masyarakat, malari tentu saja tidak dapat berdiri sendiri. Dalam kerangka ini, terdapat beberapa versi teori yang berupaya menjelaskan tentang malari (Fatah, 2010:167).

Versi atau teori yang pertama, diungkapkan oleh para aktivis mahasiswa yang terlibat dalam peristiwa itu. Ciri utama versi ini berusaha memurnikan malari sebagai "gerakan intelektual" menggugat strategi pembangunan Orde Baru beserta ekses-eksesnya yang telah terlihat jelas ketimpangan pembangunan, korupsi, kesenjangan sosio-ekonomi dan dominasi modal asing. Serta banyaknya kejanggalan lainnya dari politik Orde Baru (Fatah, 2010:168).

Teori selanjutnya datang dari "kubu" Ali Moertopo. Segera setelah peristiwa malari, Ali Moertopo mensposori sebuah buku, yang berjudul "Fakta, Analisa Lengkap dan Latar Belakang Peristiwa 15 Januari 1974". Dalam salah satu bagian bukunya ini diungkapkan bahwa malaria didalangi oleh oknum bekas PSI (Partai Sosialis Indonesia), Masyumi (Majelis Syuro Muslimin Indonesia) dan PNI (Partai Nasionalis Indonesia)-Ali Surachman. Dalam berbagai kesempatan, tentu saja tokoh PSI dan Masyumi seperti Soebadrio Sastrosatomo dan Mohamad Natsir membantah versi ini. Teori ini dinilai mengada-ada serta menampakan jelas masih bertahannya sikap historis militer Orde Baru terhadap PSI dan Masyumi (yang tidak diberikan izin berdiri kembali setelah dibubarkan Soeharto tahun 1960) (Fatah, 2010:168).
Analisis ketiga, terpaparkan dari paparan Heru Cahyono. Dalam versi ini, malari digambarkan sebagai akibat lanjutan dari maneuver-manuver politik Ali Moertopo pasca-pemilu 1971. Ali Moertopo berkeinginan membangun basis kekuasaan yang kuat dan memanfaatkannya dalam berhadapan dengan "lawan-lawan politiknya" serta dalam berhubungan dengan presiden. Selain itu Ali Moertopo juga berkeinginan untuk melanjutkan Golkarisasi dalam rangka penataan politik jangka panjang dan mendukung keinginannya yang pertama. Maka dalam versi ini malari terjadi sebagai sebuah ledakan politik akibat pergesekan yang melekat pada maneuvermanuver Ali Moertopo (Fatah, 2010:168).

Selanjutnya yang keempat, direfleksikan oleh analisis Mocthar Mas'oed dan Richard Robinson. Dalam versi ini malari digambarkan sebagai ledakan ketidakpuasan kelompok pribumi dalam strategi pembangunan Orde Baru, yaitu strategi ini amat menguntungkan kelompok (borjuis) non-pribumi dan kekuatan modal besar. Malari adalah sebuah gerakan masa pribumi yang mewadahi ketidakpuasan, gerakan ini dapat dipandang gerakan anti Cina (Fatah, 2010:169).

Versi terakhir adalah yang paling populer yaitu konflik antara Jendral Soemitro dan Ali Moertopo serta gerakan kritisme kaum muda demi menentang penanaman modal asing di Indonesia. Dalam perspektif kaum muda dalam melakukan protes terhadap pemerintahan Orde Baru. Versi ini mengedepankan kekuatan kaum muda di dalam struktur malari sebagai sebuah konflik politik (Fatah, 2010:170).

Kekecewaan para kaum muda ini sangat beralasan karena ada beberapa sebab yang membuat mereka melakukan protes keras. Hal ini karena banyaknya modal asing terutama Jepang yang menanamkan modalnya di Indonesia melalui Undang-Undang nomor 1 tahun 1967 tentang penanaman modal serta instruksi presidium kabinet No: 06/EK/IN/1/1967 
tentang tata cara penanaman modal di Indonesia sehingga arus modal terus masuk ke Indonesia tanpa bisa terbendung (Agustina, 2014:1).

Jepang pada awalnya merupakan negara yang mengalami surplus penerimaan pada pertengahan tahun 1960-an. Jepang mendapat pemasukan melalui industri petrokimia dan idustri alat-alat elektronik dan kendaraan berat. Melalui industri itu Jepang mulai mendapat tambahan dana untuk menyalurkannya keluar Jepang khususnya Indonesia. Investasi dana surplus itu dimaksudkan untuk mendapat bahan mentah untuk kebutuhan industri dalam negeri Jepang. Alasan kedua guna mendapat tenaga murah dari Indonesia serta yang terakhir adalah guna memelihara pusat-pusat pasar yang luas di wilayah Indonesia. Serta menjaga stabilitas pasar di Asia (Agustina, 2014:2).

Menurut Okada Osamu motivasi Jepang melakukan investasi di Indonesia berdasarkan survey yang dilakukan oleh kementrian perdagangan internasional tahun 1977 ada tiga alasan perusahaan Jepang melakukan investasi di Indonesia. (1) Membuka pasar, (2) mendapatkan tenaga murah dan (3) memperoleh sumber bahan mentah untuk kebutuhan industri Jepang. Sehingga menurut analisis ahli ekonomi Jepang Indonesia merupakan pasar potensial untuk investasi (Agustina, 2014:2).

Alasan ini akan dijelaskan satu persatu. Pertama adalah membuka pasar yaitu karena perdagangan Jepang yang mengalami beberapa kendala karena terbatasnnya pasar yang dapat disalurkan produk Jepang. Sehingga untuk pemecahan masalahnya dengan menyalurkannya atau mengekspor produk Jepang keluar negeri antara lain mensuplai barang atau senjata untuk amerika ketika perang Korea tahun 1950. Jepang memperoleh pendapatannya dari perjanjian keamanannya dengan Amerika. Jepang juga melakukan ekspansi perdagagangan dengan Korea Selatan sehingga membuka pintu perdagangan bagi perusahaan Jepang masuk ke Korea Selatan (Agustina, 2014:3).

Jepang melebarkan sayap perdagangan atau investasinya ke Asia Tenggara. Caranya dengan membayar ganti rugi perang yang disebabkan oleh Jepang. Banjir produk Jepang menyebabkan negara Asia Tenggara sangat bergantung pada produk Jepang. Sehingga melebihi pembayaran ganti rugi Jepang karena Perang (Agustina, 2014:3).

Kedua adalah tersedianya sumber daya alam. Wilayah Jepang sedikit akan sumber daya sehingga Jepang mampu dalam menopang industrinya. Konsumsi sumber daya antara lain kebutuhan produksi $99,8 \%$, minyak mentah $75,6 \%$, gas alam 99,6\% dan $100 \%$ Nikel dan Bauksit. Jepang mengadakan kerjasama timbal balik untuk keuntungan Jepang. Dengan begitu Jepang mendapat keuntungan berlipat dari hubungan perdagangan (Agustina, 2014:3).

Terakhir adalah kebuthan akan tenaga murah dari Indonesia. Alasan ini disebabkan karena tingginya pendapatan perkapita negara ini sehingga upah pekerja di Jepang menjadi tinggi sehingga perusahaan Jepang mulai mencari tenaga murah untuk dipekerjakan di perusahaan Jepang. Sehingga dengan kesenjangan yang tinggi membuat perusahaan Jepang mengimpor tenaga dari Indonesia yang disiplin tinggi, etos kerja tinggi dan tidak sering protes (Agustina, 2014:4).

Di tengah produksi dan pembangunan tinggi dari negara Indonesia dampak dari investasi Jepang di sektor manufaktur banyak perusahaan Indonesia terutama perusahaan tekstil yang gulung tikar, pekerja digantikan padat modal. Kekecewaan ini juga merembet menjadi perselisihan antara panglima KOPKAMTIB yaitu Soemitro dan Asisten Pribadi Presiden Soeharto yaitu Ali Moertopo karena menyebabkan protes mahasiswa, konflik 
petani dan merebaknya kerusuhan muslim dan anti-Cina (Hamid, 2013:244-245).

Ketika awal rezim Orde Baru berkuasa banyak dari kalangan non-pribumi yang mengkritisi kebijakan dari Orde Baru. Salah satunya adalah Soe Hok Gie (19421969). la mengkritik kebijakan Soeharto seperti pemberangusan para anggota PKI (Partai Komunis Indonesia) dan tentang para pemodal asing yang dikatakannya bahwa Soeharto adalah hamba dari para orang barat. Tulisannya itu la muat di "Harian Indonesia" akibatnya harian itu di bredel dan disegel pada 1969 menjelang akhir hayatnya.

Pada 1973 terjadi perdebatan yang memanas mengenai undang-undang tentang perkawinan dan perceraian. Ini akibat tekanan beberapa aktivis perempuan yang memperjuangkan hak yang tidak diatur dalam Islam. Ali Moertopo berusaha melibas rancangan undang-undang itu dalam upayanya mendepolitisasi Islam. Tapi Kenyataannya tidak sesuai prediksi disambut dengan demo 400 mahasiswa yang menentang undang-undang ini. Sementara Soemitro mendekati tokoh Islam dalam upayanya meyakinkan tokoh Islam. Sehingga undang-undang ini disahkan bulan Desember 1973 (Hamid, 2013:246).

Selain itu menentang undang-undang perkawinan para mahasiswa ini juga menentang adanya badan KOPKAMTIB pada Oktober 1973. Hal ini ditandai dengan kedatangan 11 orang mahasiswa ITB (Insitut Tekhnologi Bandung) yang mendatangi pimpinan DPR (Dewan Perwakilan Daerah Republik Indonesia) diterima serta ditemui ketua komisi XI pada saat itu Djamal Ali. Mereka dengan terangterangan mengatakan anti KOMKANTIB dang menyampaikan surat terbuka sebagai berikut:

Kami adalah sebagian dari generasi muda masa kini, masa yang dipenuhi harapan dan kekecewaan. Masa yang kami harap membawa kesejahteraan bagi rakyat Indonesia....negeri ini negeri yang aman.
Sampai kapankah status quo ini terus dipertahankan. Kami tidak mau hanya dijadikan alat permainan politik kamilah pewaris negeri ini.

Surat delegasi mahasiswa ini ditandatangani oleh ketua dewan mahasiswa ITB Muslim Tampubolon, Komarudin, Ahmad Fuad, Tahir Mujahidin dan Hindrajat. Mahasiswa Universitas Indonesia dan Trisakti juga bergerak di bawah komando Hariman Siregar, Salim Hutajulu, Gumilang Kartasasmita, Theo L. Sambuaga, Dorodjatun Jakti, Bambang Sulistomo dan Purnama. Di Jogjakarta terutama dari Universitas Gajah Mada (UGM) melakukan aksi protes di bawah komando Anhar Gonggong dan Aini Chalid serta banyak perguruan tinggi lainnya yang melakukan protes tentang kebijakan pemerintah orde baru serta KOPKAMTIB (Djoened, 2010:638).

Selain aksi mahasiswa beberapa cendikiawan dan para ahli ekonomi yang terkenal antara lain Mochtar Lubis, Kuntjoro Jakti, Suhadi Mangkusuwondo dan Maruli Panggabean mengadakan diskusi "Untung Rugi Modal Asing di Indonesia" yang mendukung tema gerakan mahasiswa. Pada 18 Desember 1973 mahasiswa Universitas Indonesia menggelar pernyataan "kebulatan tekad" untuk memperjuangkan perombakan keadaan ke-arah gerakan kehidupan kenegaraan secara menyeluruh yang ditandatangani oleh Hariman Siregar dan Judil Hery sebagai ketua dan sekretaris Dewan Mahasiswa UI.

Hari berikutnya aksi mahasiswa mahasiswa bertambah kompak dan solid pada 24 Desember 1973 lebih kurang 200 mahasiswa yang mewakili 12 Dewan Mahasiswa seluruh Indonesia berangkat dari kampus UI di Salemba bergerak menuju Bina Graha dan Cendana dengan maksud untuk berdiskusi dengan Presiden Soeharto. Hanya 12 orang yang diterima oleh petugas Bina Graha, akhirnya pada 7 Januari 1974 Presiden Soeharto mau menemui para 
perwakilan mahasiswa serta berdiskusi dengan mereka (Djoened, 2010:640).

Sampai tahun 1973 Soemitro bisa mencegah berbagai kerusuhan yang disebabkan kebijakan pemerintahan Orde Baru. Bahkan Soemitro seperti menutup mata dengan berbagai aksi yang dilakukan oleh mahasiswa. Tetapi pada 14-17 Januari tahun 1974 kesabaran mahasiswa tidak bisa dibendung lagi dengan kedatangan perdana menteri Jepang Kakuei Tanaka tahun 1974 sehingga terjadilah peristiwa kelam yang mengubah kebijakan pemerintahan Soeharto.

\section{Kronologi Peristiwa Malapetaka Lima Belas Januari (Malari)}

Peristiwa ini terjadi ketika Perdana Menteri Jepangt Kakuei Tanaka sedang berkunjung ke Jakarta (14-17 Januari 1974). Mahasiswa merencanakan menyambutnya dengan demonstrasi ketika kedatangannya. Hal ini tidak lepas dari besarnya investasi Jepang seperti yang disebutkan di atas. Karena itu kaum muda kecewa dengan kebijakan yang dibuat pemerintahan Orde Baru (Adam, 2007:81).

Sebelum kunjungan itu mahasiswa Bandung dan Jakarta membakar gambargambar Tanaka dan para pemimpin yang dianggap pro-Jepang. Sementara itu Sujono Humardhani yang dikenal sebagai pelobi pro-Jepang terkemuka dilingkaran orangorang dekat Soeharto menggelar pertemuan di Jakarta. Tapi ketika itu juga para mahasiswa membagi selebaran atau posterposter yang berisi Tritura (Tiga Tuntutan Rakyat) pada awal 1974 yang berisi pembubaran asisten pribadi, penurunan harga dan pemberantasan korupsi (Hamid, 2013:247).

Karena tidak tahan dengan aksi mahasiswa akhirnya Soeharto bersedia melakukan dialog dengan mahasiswa yang berjumlah 7 orang dan mengundangnya keistana pada 07-12 Januari 1974. Bahkan Soeharto rela untuk mendengarkan aspirasi mahasiswa serta membiarkan dirinya dihujat oleh para mahasiswa yang di wakili Hariman Siregar, Aini Chalid, dan Sahjir perwakilan dewan mahasiswa Universitas Indonesia dan Universitas Gajah Mada serta perwakilan dari Insitut Tekhnologi Bandung yang diwakili Ahmad Fuad, Muslim Tampubolon dan Imam Waluyo dari keseluruhan 200 orang perwakilan dari dewan mahasiswa seluruh Indonesia.

Tidak hanya dari kalangan mahasiswa sehari sebelum kedatangan Tanaka pendapat yang sedikit keras juga terlontar dari beberapa kalangan hal itu disampaikan oleh Juwano Sudarsono seorang pengamat ekonomi dan politik pada 13 Januari 1974. Menurutnnya kedatangan Tanaka serta kunjungannya tidak ada manfaatnya untuk kebaikan negara Indonesia. Tokoh ini pada masa itu sangat diperhitungkan karena dikenal dekat dengan kalangan aktifis mahasiswa yang ada di perguruan tinggi yang ada di Jawa Bahkan masih menurut tokoh yang sama kedatangan orang nomor dua paling penting di Jepang itu malah menimbulkan efek psikologi bagi Soeharto yang terpaksa menelan dakwaan sebagai presiden yang sangat tergantung pada negara Jepang. Bahkan menteri Sosial pada saat itu H.M.S. Mintaredja memiliki pendapat yang sama bahkan lebih keras (Fatah, 2010:172).

Jakarta memang sedang memanas dengan berbagai pergolakan seperti yang diuraikan di atas. Kedatangan Tanaka disambut dengan "sambutan yang khas" yaitu demonstrasi mahasiswa yang memang telah menunggu Tanaka sebagai momentum yang tepat untuk mengadakan demontrasi. Hal yang paling penting dalam rangka menggugat dominasi modal Jepang di Indonesia. Hal ini tidak terlepas dari masukan para ekonomi yang nyata-nyata menentang kebijakan pemerintah yang membiarkan modal negara asing terutama Jepang masuk ke Indonesia seperti Moctar Lubis, Juwano Sudarsono, dan Suhadi Mangkusuwondo mendukung aksi 
mahasiswa untuk mengadakan gerakan demonstrasi.

Pada tanggal 14 Januari 1974, aktifitas mahasiswa dari dewan-dewan mahasiswa dari beberapa universitas di Jakarta mengadakan pertemuan di kampus Universitas Indonesia untuk merancang demonstrasi untuk menyambut Tanaka. Diskusi ini dipimpin oleh Hariman Siregar sedangkan Bambang Sulistomo dan Theo Sambuaga sebagai koordinator aksi dari dewan mahasiswa Universitas Indonesia. Khusus untuk Penunjukan Theo sendiri langsung dilakukan oleh Hariman Siregar selaku ketua umum dewan mahasiswa karena Theo adalah wakil ketua dewan mahasiswa selain itu juga Theo dikenal berani dan lincah dalam memimpin aksi. Dari pertemuan inilah dihasilkan kesepakatan untuk mengumpulkan masa mahasiswa dalam rencana gerakan esok paginya dengan Universitas Trisaksakti sebagai awal gerakan. Dengan memahami gejolak politik mahasiswa pra-malari, yang telah dipaparkan dalam bagian terdahulu, maka aksi 15 Januari 1974 ini merupakan lanjutan belaka. Namun kenyataan ini menjadi amat lain karena aksi pada 15 Januari 1974 berakhir dengan huru-hara besar yang menyebabkan kerugian yang tidak sedikit. Kerusuhan ini tidak hanya para mahasiswa tetapi juga para masyarakat yang melakukan aksi penjarahan dan pengrusakan (Fatah, 2010:172-173).

Ada dua versi dalam menjelaskan masa non-mahasiswa ini: versi aparatur negara-sebagaimana diwakili oleh Soemitro dan Yoga Sugama salah satu bawahan langsung Soemitro. Mahasiswa memang telah menkoordinir dan memobilisasi masa untuk memperbesar daya aksi mereka menekan pemerintah. Karena itu sudah sewajarnya mahasiswa diminta pertanggung jawaban atas kerusakan yang mereka lakukan. Sedangkan versi mahasiswa pemasalahan ini samas ekali tidak diduga dan tidak direncanakan (Adam, 2007:82).
Adapun kronologi demonstrasi protes mahasiswa menurut Fatah dalam bukunya "Konflik, Manipulasi dan Kebangkrutan Orde Baru, Manajemen Konflik, Malari, Petisi 50 dan Tanjung Priok". Yaitu yang kemudian merebak menjadi huru-hara besar itu dapat diurut sebagai berikut: Pada sore menjelang malam hari pada tanggal 14 Agustus 1974, ratusan mahasiswa telah berada di sekitar lapangan Halim Perdana Kusuma untuk "menyambut" kedatangan Tanaka bersamaan dengan putrinya Makiko beserta rombongan pejabat Jepang lainnya. Penjagaan keamanan sangat ketat. Namun beberapa mahasiswa dapat menerobos masuk penjagaan dan sempat memperlihatkan poster sewaktu Tanaka mendarat, pukul 19.45 WIB. Malam hari itu juga para mahasiswa kemudian berkumpul di kampus Universitas Indonesia untuk mengadakan persiapan bagi aksi besar yang direncanakan akan dilaksanakan esok harinya (Fatah, 2010:173-174).

Karena situasi yang tidak kondusif maka Presiden Soeharto menggunakan helikopter bukan dengan mobil karena situasi yang memanas di Jakarta karena aksi mahasiswa. Hal ini merupakan sesuatu yang tidak diduga oleh para mahasiswa karena mereka berencana mencegat presiden dan perdana menteri Jepang di daerah bandara sebelum menuju istana. Mahasiswa sangat kecewa karena gagal menyampaikan aspirasi mereka terhadap Tanaka dan putrinya.

Untuk melampiaskan kekecewaan di malam yang sama mereka juga menyebarkan pamflet-pamflet dan poster yang berisi wajah Tanaka dan membakarnya. Mereka juga mengajukan Tritura (Tiga Tuntutan Rakyat), yang berisi bubarkan asisten pribadi, penurunan harga dan pemberantasan korupsi. Mereka juga meminta aparat untuk mengusir Tanaka. Tetapi walaupun begitu mereka tetap merencanakan aksi damai (Hamid, 2013:247). 
Pada 15 Januari 1974, aksi yang telah direncanakan itupun kemudian dijalankan. Sebagaimana telah direncanakan sebelumnya masa berkumpul di lapangan Monas, pagi hari 15 Januari 1974. Sementara itu pada pukul 08.00 WIB telah berkumpul masa juga di halaman kampus Universitas Indonesia yang berasal dari berbagai perguruan tinggi yang ada di Jakarta serta perwakilan perguruan tinggi dari daerah Jawa lainnya. Masa yang dikoordinir oleh Bambang Sulistomo dan Theo Sambuaga ini, sebagaimana telah direncanakan kemudian bergerak menuju kampus Trisakti. Perjalanan masa menuju kampus Trisakti telah terjadi beberapa perkembangan (Fatah, 2010:174).

Pertama, semakin lama masa makin bertambah oleh bergabungnya masa yang telah menunggu di jalanan antara SalembaGrogol. Sulit bagi identifikasi mana mahasiswa yang telah memiliki kesepakatan koordinasi dan masa non-mahasiswa yang ikut tergabung tanpa diketahui seluruh rencana. Kedua masa akhirnya terpencar menjadi dua bagian besar, sebagian bergabung dengan lapangan monas dan sebagian lain menuju Trisakti. Ketiga masa yang bergerak dan makin menyemut ini terutama yang menuju kearah lapangan Monas, menurunkan bendera penyambutan untuk Tanaka setengah tiang, seakan-akan duka masyarakat atas kedatangan Tanaka. Keempat pengendalian masa menjadi sulit dilakukan, terlebih-lebih masa yang bergerak telah semakin heterogen, bercampur menjadi satu (Fatah, 2010:175).

Masa yang umumnya terdiri dari para mahasiswa yang kemudian berkumpul di Universitas Trisakti akhirnya bergerak memakai kendaraan ke pusat gerakan lapangan Monas dan daerah seputar istana. Tujuan ini jelas bahwa mereka menuntut Tritura dan menemui Presiden Soeharto dan Perdana Menteri Tanaka. Mereka semakin beringas dan semakin tidak terkendali (Fatah, 2010:175).
Melihat hal di atas Bambang Sulistomo yang menjadi koordiantor aksi kebingungan dan tidak bisa berbuat banyak. Hal ini sangat jauh dari perkiraannya yang merencanakan aksi damai. $\mathrm{Hal}$ ini kemudian didiskusikannya pada Theo Sambuaga tetapi pemuda ini juga kebingungan dalam menyikapi masa yang semakin beringas. Merekapun hanya bisa menenangkan masa untuk tidak berbuat anarkis.

Jendral soemitro kemudian menemui masa untuk menenangkan aksi masa yang beringas. Pada saat itu Soemitro memakai mobil buatan Jepang yang membuat masa semakin marah. Soemitro berjanji dari mobilnya untuk melakukan audensi antara mahasiswa dan perdana menteri Jepang yaitu Tanaka. Hal itu dibalas mahasiswa dengan meneriakan tidak ada lagi dialog dalam ruangan tetapi yang ada hanya dialog jalanan, hal ini disampaikan berdasarkan pengakuan jenderal Soemitro pada harian Tempo pada saat itu.

Ancaman Soemitro yang mengancam mahasiswa apabila aksi pengrusakan dianggap sebagai penghianatan kepada negara tidak digubris mahasiswa. Soemitro kemudian menyuruh pasukan keamanan untuk menahan mahasiswa agar menjauhi istana. Hal ini dilakukan karena Soemitro khawatir akan sikap mahasiswa yang semakin beringas dan mempermalukan presiden di depan Tanaka (Caldwell, 2011:320).

Pada saat yang sama petugas keamanan semakin tidak sabar menghadapi masa mahasiswa. Masa didesak untuk menjauhi istana. Kerumunan ini kemudian dihadang oleh para penonton dan yang berasal dari masyarakat yang melakukan bentrok dan diduga melakukan pengrusakan atas suruhan Ali Moertopo dan Liem Ban Kie. Mereka juga menyatroni kota dan juga melakukan aksi pengrusakan (Hamid, 2013:248).

Kerusuhan semakin melebar dengan aksi gabungan antara mahasiswa dan 
masyarakat. Pengrusakan dan pembakaran kendaraan juga dilakukan tidak hanya milik pribadi tetapi juga kendaraan milik $\mathrm{ABR}$ (Angkatan Bersenjata Republik Indonesia). Kantor Astra yang terkenal sebagai importer Jepang termasuk show room dirusak masa. Pusat penjualan mobil baru dan bekas dirusak dan dibakar tidak terkecuali mobil yang ada di sana. Termasuk perusahaan PT Insan Apollo, PT Subaru dan perusahaan lainnya. Mobil dan motor yang ada di daelar dirusak dan dihancurkan terutama mobil buatan Jepang (Fatah, 2010:177).

Menjelang sore proyek Senen yang sudah dijaga aparat keamanan akhirnya tidak terselamatkan. Pusat pertokoan terbesar di Jakarta itu dirusak dan dijarah. Mobil pemadam kebakaran yang datang ke daerah itu tidak dapat berbuat banyak karena juga ikut dirusak masa. Di malam hari sebuah insiden proyek senen menyebabkan aliran listrik terputus ke daerah itu. Gerakan anti Jepang kemudian meluas menjadi gerakan anti kemewahan dan kemaksiatan. Gerakan juga dilanjutkan pada keesokan harinya, 16 Januari 1974. Larangan berkumpul lebih dari lima orang diberlakukan tapi tidak efektif berjalan. Kantor Pertamina dan Cola-Cola tidak luput untuk mendapat pengrusakan dan tinggal puing dan terus berlanjut sampai pukul 22.00 WIB (Fatah, 2010:178).

Menurut berbagai sumber, dalam kerusuhan 15 dan 16 Januari itu, 11 orang meninggal, 177 mengalami luka berat, 120 luka ringan dan 755 orang ditahan. Sementara itu 807 mobil dan 187 sepeda motor rusak atau dibakar, 144 bangunan dan 1 pabrik rusak atau terbakar dan sejumlah $160 \mathrm{Kg}$ emas hilang dijarah (Hamid, 2013:248).

\section{Dampak Peristiwa Malapetaka Lima Belas Januari (Malari)}

Dampak peristiwa malari dapat dilihat dari berbagai sudut pandang atau berbagai bidang yang antara lain berkaitan langsung dengan kehidupan berbangsa dan negara yang dapat dijelaskan sebagai berikut:

\section{a) Ideologi}

Lahirnya Orde Baru yang berarti sebuah Orde dengan tekad kuat untuk untuk melaksanakan Pancasila dengan tekad yang kuat untuk melaksanakan Pancasila dan Undang-Undang Dasar 1945 secara murni dan konsekuen menjadi senjata ampuh bagi Soeharto untuk memperkuat kedudukan dan posisinya. Dengan demikian peranperan tokoh lain yang mendukung kemerdekaan kurang ditonjolkan (Adam, 2006:62). Tetapi setelah peristiwa malari tujuan untuk menguatkan Pancasila dan memurnikan Undang-Undang Dasar 1945 semakin ditingkatkan. Bahkan para mahasiswa yang menentang dan menghina ideologi serta Pancasila langsung dipenjarakan atau dihilangkan paksa. Bahkan pokokpokok empat pilar kebangsaan itu dimasukkan dan dilatih para pelajar dan para pegawai negeri sipil. Serta yang paling penting di universitasuniversitas di Indonesia dimasukkan ujian negara yang salah satu bagian atau soalnya tentang Pancasila (Adam, 2006:62).

Usaha menguatkan citra rezim Soeharto yang bersih, berwibawa dan penuh heroik dilakukan di antaranya melalui penulisan sejarah yang disponsori pemerintah dalam bentuk proyek-proyek penulisan sejarah yang disponsori pemerintah dan macammacam kegiatan lain dan diterbitkan oleh bagian penerbitan arsip nasional. Ini jelas sebagai usaha untuk mengubah sejarah yang ada serta ideologi yang diikuti Orde Baru (Rauf, 1998:63).

Bahkan pada 1980 ada upaya dari pemerintah untuk mengurangi kedudukan serta agama Islam dalam 
kehidupan masyarakat. Pemerintah cenderung mengharuskan masyarakat untuk lebih memperhatikan ideologi Pancasila dibandingkan dengan Islam. Di sisi lain juga ada beberapa pihak dalam pemerintah yang melakukan adu domba antara Islam dengan pemerintah yang berideologi Pancasila sehingga terjadilah kerusuhan Tanjung Priok yang memakan banyak korban jiwa karena konflik ini (Fatah, 2010:233).

b) Politik

Sistem politik Orde Baru setelah kerusuhan malari yang pada awalnya sangat terbuka dan menjujung tinggi kebebasan berpendapat dan berbeda dengan Orde Lama menjadi tertutup, otoriter, represif, serta terdapat dominasi negara terhadap masyarakat. Semua penentang serta hal-hal yang terlibat dalam kerusuhan ditangkap serta diadili. Tidak sedikit yang diculik dan tidak diketahui nasibnya hingga kini (Rauf, 1998:12).

Kebijakan politik ini dilakukan untuk menciptakan stabilitas politik. Aparat represif menjadi pelaksana utama kebijakan ini, sementara aparat ideologis menjadi agen yang terus menerus memasyaratkan dan mensosialisasikan ideologi dan stabilitas public. Sasaran utama itu adalah terciptanya suatu stabilitas demi kemajuan Orde Baru (Fatah, 2010:80).

Media-media

yang

menyudutkan serta menghina pemerintahan Orde Baru dibredel dan ditutup. Kebebasan berbicara dan berpendapat dibungkam. Mahasiswa harus kembali masuk kampus tanpa mencampuri urusan pemerintahan. Bahkan peran media elektronik harus menonjolkan keunggulan dan kebaikan pemerintahan Orde Baru (Adam, 2006:12).

Bahkan sistem politik ini menggunakan prinsip sentralisme kekuasaan. Artinya dalam sistem ini seluruh wilayah yang ada di Indonesia semuanya diatur oleh pusat yaitu Jakarta. Dalam pendapat hasil daerahpun ada ketimpangan dan ketidakadilan dalam pembagian pendapatan daerah yaitu 70:30 \%, berarti daerah hanya mendapat dana $30 \%$ dan selebihnya untuk pusat. Kekayaan negara dimonopoli oleh pusat dan tidak sedikitpun diberikan kepada daerah untuk membangun daerahnya (Rauf, 1998:13).

Dalam sistem politik yang demikian keputusan berdasarkan kerangka legal rasional dan berdasarkan hubungan personel. Di sini hukum etik dan moral menjadi sesuatu yang tidak signifikan. Kekuasaan menjadi panglima dan pemerintahan yang bersih dan berprestasi. Tetapi sayangnya di sinilah menemukan distorsi, mulai dari korupsi, kolusi dan nepotisme (KKN), serta pelanggaran HAM yang luas (Rauf, 1998:13).

\section{c) Ekonomi}

Kebijakan ekonomi setelah kerusuhan malari adalah suatu kemajuan dibandingkan rezim sebelumnya bahkan hingga saat ini. Banyak pembangunan dan kemajuan yang sekarang dirasakan itu dibuat oleh pemerintahan Orde Baru. Hal ini membuktikan bahwa pemerintahan ini walaupun dianggap korupsi tetapi juga yang paling dikenal serta dikenang oleh anak penerusnya (Fatah, 2010:71).

Corak pembangunan macam itu didukung sekurang-kurangnya oleh tiga pilar utama. (1) Kebijakankebijakan ekonomi yang pragmatis, (2) stabilitas otokratis, (3) dukungan 
lingkungan internasional. Sehingga terciptanya ekonomi yang kuat dan tahan akan goncangan ekonomi setidaknya sampai tahun 1998. Tanpa itu ekonomi sangat rentan dengan krisis (Fatah, 2010:71).

Dukungan internasional ini didapat dari IMF (International Monetery Found), International Government Group On Indonesia (GGl), modal Jepang yang makin besar setelah kerusuhan malari karena tidak ada lagi penentang. Selanjutnya juga banyaknya perusahaan yang masuk ke Indonesia terutama perusahaan Jepang seperti Panasonic, Suzuki, Yamaha, Honda dan banyak laginya perusahaan asing yang masuk ke Indonesia. Sebagai gantinya mereka membayar pajak yang dipakai pemerintah untuk pembangunan negara (Adam, 2006:38).

Persoalan hutang luar negeri menjadi perhatian yang serius dan ini menjadi persoalan ekonomi dan politik. Persoalan politik mengingat hutang Orde Lama sebagian besar berasal dari negara-negara komunis yang berkaitan dengan Gerakan 30 September 1965. Pemerintahan Soeharto cenderung berpaling ke blok barat. Hal ini dilakukan agar kebijakan yang salah dapat diperbaiki oleh pemerintahan Orde Baru dan merehabilitasi dukungan Amerika dan sekutunya untuk membantu Indonesia (Fatah, 2010:73).

Usaha Soeharto mulai menampakkan hasil pemerintah mulai mencicil hutang pada negara-negara komunis serta mulai pembangunan seperti pembangunan jalan serta fasilitas lainnya seperti gedung pencakar langit. Hanya saja kekuarangan Orde Baru, keluarga presiden Soeharto dan orang dekatnya sangat berkuasa seperti pendirian pabrik tepung Bogasari yang dikelola Liem Sioe Lieng dan Ny. Tien Soeharto, serta pemberian monopoli cengkeh pada Tommy soeharto yang banyak merugikan petani cengkeh. Sehingga walaupun tampak tangguh diluar tapi ekonomi pemerintahan Orde Baru sedikit demi sedikit digerogoti keluarganya (Adam, 2006:39).

d) Pertahanan dan Keamanan Negara

Peristiwa kerusuhan dan penjarahan yang dilakukan oleh masa malari sangat memalukan Soeharto. $\mathrm{Hal}$ ini kemudian dilakukan dengan dengan memaksa dalam artian meminta pertanggung jawaban Soemitro dengan memintanya mundur dari jabatannya sebagai PANGKOPTIB dan digantikan laksamana Soedomo. Panglima yang baru ini kemudian mengambil langkah-langkah yang dianggap perlu untuk menyelamatkan wajah pemerintah yang dipermalukan di depan tamu negara (Djoened, 2010:642).

Sejumlah tokoh mahasiswa yang dianggap sebagai tokoh gerakan kemudian ditangkap seperti Hariman Siregar, Theo L. Sambuaga, Syahrir, Bambang Sulistomo, Aini Chalid, Muslim Tampubolon, Gumilang Kartasasmita, Salim Hutajulu dan banyak tokoh lainnya. Mereka ditangkap dengan tuduhan yang berat dan tuduhan penghianatan kepada negara. Mereka dijebloskan ke-penjara tanpa disertai dengan bukti yang cukup.

Tidak hanya dari kalangan mahasiswa para pengacara dan pengamat hak asasi mahasiswa juga tidak luput dari penangkapan dengan adanya undang-undang anti subservi. Nama-nama besar tidak luput dari penangkapan seperti Adnan Buyung Nasution, Yap Tian Hien dan banyak 
tokoh lainnya. Kedua tokoh ini ditangkap karena komentarnya yang membela aksi mahasiswa dan siap berdiri paling depan dalam membela mahasiswa melalui YLBHI (Yayasan Lembaga Bantuan Hukum Indonesia). Kedua tokoh ini dilepaskan pada tahun 1975.

$$
\text { Sejumlah persidangan }
$$

kemudian digelar setelah kejadian malari. Dari puluhan orang yang dikenai tuduhan" biangkeladi" hanya tiga orang yang disidangkan yaitu Hariman Siregar, Syahrir dan Aini Chalid. Fakta ini menjelaskan mengapa "pemerintah" menunjuk pengacara yang notabene merupakan simpati pada PSI seperti S. Tasrif, Sutan Datuk Mangkuto Nursjirwan. Kasus ini tetap sulit dibuktikan dan hukum orde barulah yang menang. Persidangan Hariman Siregar memberi banyak contoh manipulasi yang bertujuan membuktikan kasus ini. Hariman telah bersalah karena la "1) (bertindak) dengan sengaja atau mengetahui; 2) menggasir ideologi negara atau tujuan negara; 3 ) menggasir kekuasaan negara dan martabat pemerintah; menyebarluaskan permusuhan, keributan......; 5) mengganggu industri, produksi dan distribusi " . (petisi 24) dikutip sebagai untuk dakwaan ini (Hamid, 2013:250)

Ketiga terdakwa akhirnya dijatuhi hukuman yang relatif ringan mengingat di bawah undang-undang (UU) Antisubservi mereka bisa saja dijatuhi hukuman mati. Hariman Siregar dijatuhi empat setengah tahun, Aini Chalid dua tahun tiga bulan serta Syahrir enam setengah tahun. Namun banyak dari mereka yang disiksa tanpa diadili serta ditahan dan dihilangkan oleh pemerintah Soeharto (Hamid, 2013: 252).
Keamanan Negara juga setelah peristiwa malari semakin ditingkatkan. Stabilitas ini diperlukan menurut Orde Baru untuk menunjang ekonomi pragmatis yang sangat berdekatan dengan barat. Stabilitas ini dilakukan dengan penghancuran yang dianggap musuh negara yang utama dan sistematis. Meliputi kekuatan yang merongrong kewibawaan Orde Baru seperti media, mahasiswa serta tokoh politik yang dianggap membahayakan (Fatah, 2010:80).

Selain pihak-pihak di atas ada lagi yang diperhitungkan dapat menggulingkan kekuatan Orde Baru yaitu Islam yang menjadi agama mayoritas masyarakat Indonesia. Bagi rezim Orde Baru sejak awal kelahiran tidak diperkenankan penghidupan kembali Masyumi (Majelis Syuro' Muslimin Indonesia) serta pelarangan berdirinya Partai Demokrasi Indonesia Islam (PDII) (Adam, 2006:80).

Persepsi negara yang sangat memusuhi Islam juga sangat terlihat dengan ditemukan dokumen yang berisi keinginan Ali Moertopo dan para kawan-kawan untuk memecah belah Islam dan menguasai umat Islam dengan pertentangan antara Pancasila dan Islam. Dalam wujudnya yang lebih kontemporer, persepsi Orde Baru yang menempatkan Islam sebagai musuh negara dengan dipaksakan asas tunggal (Fatah, 2010:82).

Penyingkiran musuh utama negara Orde Baru adalah demi kelanggengan dan stabilitas politik. Hal yang paling penting adalah semua kekuasaan negara terpusat ditangan presiden. Manajemen ini ini dimungkinkan karena tidak ada lagi pihak yang kuat untuk menentang kebijakan Orde Baru. Sentralisasi 
kekuasaan di tangan presiden juga membatasi kekuasaan legislatif dan yudikatif.

\section{Peristiwa Malari Sebagai Sumber Pembelajaran Sejarah}

Adapun strategi yang digunakan oleh peneliti untuk menjadikan peristiwa malari sebagai sumber pembelajaran sejarah harus mengetahui kurikulum yang dipakai di SMA Sriguna Palembang. Kemudian mencari silabus pembelajaran serta mencari materi yang sesuai dengan peristiwa malapetaka lima belas Januari.

Kurikulum yang dipakai oleh Sekolah Menengah Atas Sriguna Palembang adalah kurikulum 2013. Sekolah ini telah meninggalkan kurikulum lama yaitu kurikulum KTSP 2006 Sedangkan kompetensi Dasar yang dipakai untuk materi malari tahun 1974 adalah 4.8 Merekontruksi perkembangan politik, ekonomi sosial dan budaya pada masa Orde Baru dan Reformasi. Sedangkan materi pokok yang membahas peristiwa malaria tergabung dalam "Perkembangan politik, Sosial, Budaya dan Pendidikan Pada masa Orde Baru serta dampaknya bagi kehidupan bangsa Indonesia. Walaupun tidak dibahas secara jelas tentang peristiwa malari tapi dapat disimpulkan melalui kehidupan politik dan sosial budaya yang bisa dimasukkan materi malari tahun 1974.

Kemudian penulis membuat bahan ajar serta membuat rencana pelaksanaan pembelajaran (RPP) sesuai dengan materi yang dimaksud. Serta memasukkan materi tentang peristiwa malapetaka lima belas Januari tahun 1974. Apabila bahan ajar ini dikatakan layak oleh guru matapelajaran sejarah maka guru tersebut dapat menguji cobanya di Sekolah Menengah Atas Sriguna Palembang.

\section{Pembahasan}

Berdasarkan hasil observasi dan wawancara di SMA Sriguna Palembang. Peneliti mengetahui bahwa sekolah ini menggunakan kurikulum baru yaitu kurikulum 2013 sesuai dengan ketetapan pemerintah. Pada silabus pembelajaran sejarah kelas XII pada kompetensi dasar 4.8 Merekontruksi perkembangan politik, ekonomi sosial dan budaya pada masa Orde Baru dan Reformasi. Sedangkan materi pokok yang membahas peristiwa malaria tergabung dalam "Perkembangan politik, Sosial, Budaya dan Pendidikan Pada masa Orde Baru serta dampaknya bagi kehidupan bangsa Indonesia. Walaupun tidak dibahas secara jelas tentang peristiwa malari tapi dapat disimpulkan melalui kehidupan politik dan sosial budaya yang bisa dimasukkan materi malari tahun 1974.

Pada kelas XII berjumlah 7 kelas yaitu kelas XII IIS berjumlah 4 kelas dan kelas XII MIPA ada 3 kelas. Kemudian peneliti melakukan observasi tentang kekuarangan dan kelebihan sumber pembelajaran yang ada di kelas XII serta mencocokkan layak atau tidaknya materi peneliti dimasukkan dalam pembelajaran yaitu Peristiwa Malapetaka Lima Belas Januari Tahun 1974 Sebagai Sumber Pembelajaran Sejarah Sekolah Menengah Atas sriguna Palembang.

Sebelum mengadakan penelitian menyiapkan bahan ajar dan RPP sesuai bahan ajar yang ingin diteliti. RPP dan bahan ajar itu dikonsultasikan pada guru mata pelajaran sejarah kelas XII yaitu Ahmad Humaidi S.Pd. guna mengetahui kelayakan materi ini. Setelah diketahui bahwa materi ini layak maka bahan ajar ini dapat digunakan oleh guru tersebut untuk mengajarkannya pada kelas XII tahun berikutnya. Berdasarkan hasil penelitian yang dilakukan di SMA Sriguna Palembang tentang Peristiwa Malapetaka Lima Belas Januari Tahun 1974 Sebagai Sumber Pembelajaran Sejarah Sekolah Menengah Atas Sriguna Palembang dapat dijadikan sumber pembelajaran tambahan yang dapat dijadikan wawasan pengetahuan sejarah politik serta kontroversi yang banyak ditutupi 
oleh pemerintah karena banyaknya pihak yang bermain dalam konflik ini.

Tidak hanya peristiwanya saja yang dapat siswa ketahui melainkan juga latar belakang sebelum peristiwa serta dampak yang ditimbulkan seperti ideologi, politik, ekonomi serta pertahanan dan keamanan. Sehingga wawasan para siswa dapat terbuka dan mengetahui kebenaran dari peristiwa malari tahun 1974.

\section{SIMPULAN}

Terjadinya malari tahun 1974 disebabkan karena berbagai sebab yang kemudian menemukan momen yang tepat untuk keluar dan menyatakan ketidaksetujuan pada pemerintahan Orde Baru. Seperti sikap kritis kaum muda yang menentang penanaman modal asing di Indonesia serta pertentangan antara Ali Moertopo dan Soemitro dalam menarik perhatian presiden Soeharto.

Dampak yang ditibulkan malari ini menjadi semakin kompleks. Dari segi ekonomi pemerintah semakin merapat pada Jepang dan negara barat lainnya dibandingkan komunis. Dari segi politik pemerintah semakin represif dan otoriter dalam menghadapi aksi masa. Segi Hukum dan keamanan para terdakwa kerusuhan malari dihukum dengan berat bahkan ada beberapa aktivis yang diculik dan dihilangkan paksa tanpa diketahui nasibnya.

Untuk merumuskan peristiwa malari sebagai sumber pembelajaran sejarah di SMA Sriguna Palembang. Bahwa sekolah ini menggunakan kurikulum baru yaitu kurikulum 2013 sesuai dengan ketetapan pemerintah. Pada silabus pembelajaran sejarah kelas XII pada kompetensi dasar 4.8 Merekontruksi perkembangan politik, ekonomi sosial dan budaya pada masa Orde Baru dan Reformasi. Bahwa untuk membuat materi ini dapat diajarkan dengan membuat bahan ajar yang dapat diajarkan dan dikonsultasikan dengan guru mata pelajaran layak atau tidak untuk dijadikan sumber pembelajaran.

\section{DAFTAR PUSTAKA}

Adam, Asvi Warman. 2007. Seabad Kontrofersi Sejarah. Yogyakarta: Ombak.

2010. Menguak Misteri

Sejarah. Jakarta: Kompas. 2006. Soeharto Sehat. Yogyakarta: Galang Press.

Agustina, Widiarsi. 2014. Massa Misterius Malari. Jakarta: Tempo Publishing.

Caldwell, Malcolm dan Ernst Uterch. 2011. Sejarah Alternative Indonesia. Yogyakarta: Djaman Baroe.

Djoened, Marwati, Poeponegoro. 2010. Sejarah Nasional Indonesia IV Edisi Pemutakhiran. Jakarta: Balai Pustaka.

Didi. 2008. Apakah Soeharto Pahlawan. Yogyakarta: Bio Pustaka.

Fatah, Eep Saefullah. 2010. Konflik, Manipulasi dan Kebangkrutan Orde Baru Manajemen Konflik, Malari, Petisi 50 dan Tanjung Priok. Jakarta: Burung Merak Press.

Hamid, Usman. 2013. Penyelewengan Hukum dan Teror Propaganda 19651981. Depok: Komunitas Bambu.

Hidayat, Amir F. 2006. Ensliklopedia Negara-Negara Dunia. Bandung: Pustaka Grafika.

Pambudi, A. 2009. Supersemar Palsu Kesaksian Tiga Jendral. Yogyakarta: Media Pressindo.

Rauf, Maswadi. 1998. Mengubur Sistem Politik Orde Baru. Bandung: Mizan.

Tirtarahardja, Umar dan Sulo, S.L. La Sulo. 2005. Pengantar Pendidikan. Jakarta: Rinneka Cipta. 